\title{
Design Evaluation Process for Existing Waste Removal Design Documents (U)
}

by

P. D. Smith

Westinghouse Savannah River Company

Savannah River Site

Aiken, South Carolina 29808

This paper was prepared in connection with work done under the above contract number with the U.S.

Department of Energy. By acceptance of this paper, the publisher and/or recipient acknowledges the U. S.

Government's right to retain a nonexclusive, royalty-free license in and to any copyright covering this paper, along with the right to reproduce and to authorize others to reproduce all or part of the copyrighted paper. 


\section{DISCLAIMER}

This report was prepared as an account of work sponsored by an agency of the United States Government. Neither the United States Government nor any agency thereof, nor any of their employees, makés any warranty, express or implied, or assumes any legal liability or responsibility for the accuracy, completeness, or usefulness of any information, apparatus, product, or process disclosed, or represents that its use would not infringe privately owned rights. Reference herein to any specific commercial product, process, or service by trade name, trademark, manufacturer, or otherwise does not necessarily constitute or imply. its endorsement, recommendation, or favoring by the United States Government or any agency thereof. The views and opinions of authors expressed hercin do not necessarily state or reflect those of the United. States -Government or any agency thereof.

This report has been reproduced directly from the best available copy.

Available to DOE and DOE contractors from the Office of Scientific and Technical Information. P. O. Box 62, Oak Ridge, TN 37831: prices available from (615) $576-8401$.

Available to the public from the National Technical Information Service, U. S. Deparment of Commerce, 5285 Port Royal Rd., Springfield. VA 22161 


\section{DISCLAIMER}

Portions of this document may be illegible in electronic image products. Images are produced from the best available original document. 
HIGH LEVEL WASTE MANAGEMENT WASTE REMOVAL ENGINEERING
WSRC-TR-95-0230

REVISION: 0

KEYWORDS:

Design Documents

Waste Removal

Design -Validation Evaluation P.19 $1.9 S$

RETENTION:

Permanent

CLASSIFICATION:

Unclassified

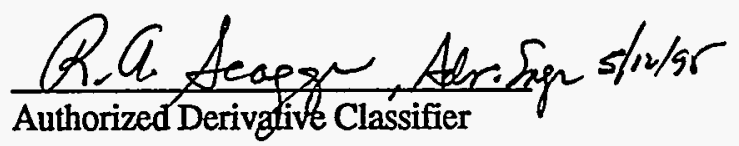

DESIGN EVALUATION PROCESS FOR

EXISTING WASTE REMOVAL DESIGN DOCUMENTS (U)

by

P. DOCK SMITH, III

MAY 12, 1995

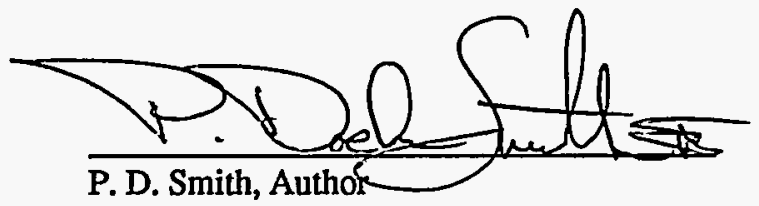

Mppeinn s/18/95

M. P. Reimnitz, Technical Reviewer

B1 Len $5 / 1945$

B. L. Lewis, WRE Manager

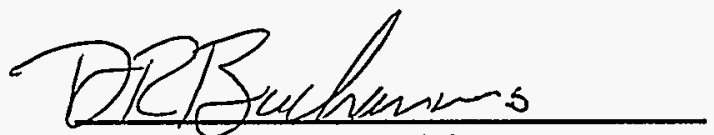

D. R. Buchanan, WRPE Manager
$5-12-95$

Date

$5-18-95$

Date

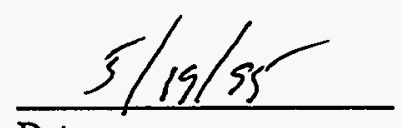

Date

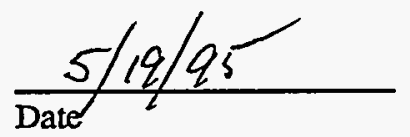




\section{Design Evaluation Process for Existing Waste Removal Design Documents}

\section{ABSTRACT}

$\therefore$ This document provides guidelines for implementing Engineering's responsibility relating to evaluating the adequacy of existing project design outputs. At this time, there exists design documents that were prepared and approved for modifications to operating facilities, that may or may not have been constructed, but have never been turned over to the Operating Facility Management. The process described herein describes the methodology to perform an evaluation of these existing designs and document the findings. The key elements in this process are (1) to evaluate the existing design for general adequacy of the design, (2) to evaluate the existing design due to changes subsequent to the issuance of the documents (i.e. lessons learned, codes or standards change, changes to input documents, ect.), and (3) to verify the existence of critical supporting documentation in the areas of personnel safety, facility safety or environmental . compliance.

\section{BACKGROUND}

Waste -Removal Projects began with original design input and output being performed by DuPont. These projects install new components, as well as upgrade existing components, to the facilities and equipment in the $\mathrm{F}$ and $\mathrm{H}$ Tank Farms. These modifications support the removal and processing of salt and sludge wastes prior to being sent to the vitrification process in the Defense Waste Processing Facility (DWPF). Design work was performed by DuPont and other Architect / Engineering (A/E) firms under contract to DuPont as Full Service Contractors (FSC). Changes in both site mission and funding availability have delayed the design and construction work at various times. There has also been a transition from DuPont to the Westinghouse / Bechtel team and reassignment:of two Full Service Contracts to a Project Engineering Services Contractor.

Most recently, the process for modifying facilities at SRS has changed with the implementation of Procedure Manual E7, "Conduct of Engineering and Technical Support". The procedures in E7 formulate a new culture of project execution and facility modification. Before the implementation of E7, drawings were prepared, checked, reviewed, approved and issued to Document Control. No formal mechanism indicated the status of the modification on the issued drawings. Modifications could be installed, partially installed, awaiting construction resources, "on hold" due to funding, canceled or abandoned without formal status to the drawings. E7 has brought more formality to the modification process. Drawings are not directly modified until the modification is verified as complete. Intermediate documents, Design Change Packages (DCPs) with Design Change Notices (DCNs) or in limited cases Design Change Forms (DCFs) are used as implementing documents. Drawings incorporate modifications from the intermediate documents after installation is verified.

Additional changes may have also occurred. The Operating Facilities modify components through normal component replacement and the Division Managed Modification process. The Maintenance Baseline Program institutes new drawings that portray current as-installed conditions. Design that was not installed is superseded. These and other conditions may be present. 


\section{INTRODUCTION}

Due to changes that have occurred, it is prudent for the design basis, design outputs, and construction implementation documentation be scrutinized by the current Design Authority and Project Team. The design inputs need to be evaluated against current Authorization Basis and Operating Facility requirements. This evaluation should not apply new requirements. But it is essential to identify and document the original criteria, such as code of record, as part of the acceptance of the modification by the Operating Facility. Design outputs that are effected by these changes need to be identified and evaluated. Design that is not implemented, implemented design that has not incorporated as-built conditions, and documents that support design (e.g. calculations, permits, ect.) should be evaluated to identify items that were possibly lost in transition or never developed. Construction verification records also need to be located and reviewed for completeness.

The acceptance of any modification by the Operating Facility Management will need to be justified based on the current Authorization Basis and the Operating Facility requirements. The justification of existing documents will be based on meeting the technical requirements. The documentation does not need to be in currently used formats. Nevertheless, documentation does need to address and fully support the requirements.

\section{DISCUSSION}

During the Design Evaluation Process, the engineer(s) performing the review shall:

- understand the requirements and the technical basis of the modification

- review the existing design input document against output documents for alignment

- understand the technical mode of operation

- document the portion of the design that is adequate for the intended service

- document the design documents which are missing or deficient

- document that the modification, when implemented, can be tested and operated in a safe manner

This set of "guidelines" represent the process to verify that an existing design is adequate for construction, testing and acceptable for Turnover. Conditions may exist within the existing design which may require further corrective action. The evaluation phase will identify conditions that warrant further action. Some conditions can be justified by using reasonable engineering judgment such that further corrective action is not required. Other items may require further corrective action such as additional design, calculations, or startup testing.

This assessment needs to be performed on a System basis.

This process for the evaluation of existing design will include the following steps:

- definition of the scope of the existing design and design basis documents

- acquisition of the existing design documents and supporting documents (i.e... calcs, ect.)

- evaluation of the existing design

- document acceptable conditions

- justify conditions deemed acceptable using reasonable engineering judgment

- prepare formal evaluation document

- using the Design Verification Report document format (see E7, 2.40) OR

- other approved documentation vehicle

- approval of document by the Technical Agericy and Design Authority and

- revise and reissue upon completion and / or disposition of deficiencies 


\section{EVALUATION PROCESS}

Define the scope boundary of the evaluation review. Identify the existing design input documents. Note any revisions to the input documents subsequent to the completion of the design output documents.

Obtain all engineering documentation (i.e.. drawings, calculations, specifications, ect.) that supports the scope being verified.

\section{Specific concerns -}

There are several areas of concern that relate to personnel safety, facility safety or environmental compliance. These concerns will require supporting documentation to be retrievable, or justification of why it is not required, or listed as a deficiency to be prepared later. These concerns are :

- High temperature (greater than $150^{\circ} \mathrm{F}$ ) piping systems (see SRSESM 15060-01-R, 5.4)

- requires thermal expansion analysis (stress calcs)

- Over Pressure Protection

- pressure relief verification as applicable per Manual 1B, Procedure 5.18

- Pressure Relief Valve Verification Record (OSR 8-193)

- Temperature -Pressure Relief Valve Verification Record

- Nonreclosing Pressure Relief Device Verification Record

- pressure design must comply with the referenced industry code

- normally ASME B31.3 for most p-code

- High Voltage

- coordination curves

- Power Services Utilization Permit

- Protective Relaying

- electrical relays

- interlocks

- Environmental

- Federal Facilities Agreement - secondary containment requirements

- Domestic Water Permit

- air / water discharges

- Environmental Compliance Checklist

- NEPA documentation

- Hazardous Chemicals

- DHEC regulations

- Radiological

- ALARA reviews / checklist

- shielding calculations

- Structural

- structural calculations

- Component Set Points 


\section{Generic Cóncerns -}

The entire scope of the evaluation needs to be reviewed for the alignment of the design output with the design input (BDR, FPR, FDC, ect.). Document the evaluation in the format of: a design verification report (see E7, 2.40) OR a matrix of detailed input requirements to output document requirements $O R$ other approved report format

Review the design output against the DPHR. Does the design output address the QAR requirements?

The Code of Record must be reviewed to ensure that it is still valid. The concern is that some SRP Standards may have been voided. The design output documentation will be reviewed for voided Standards. If none are found, document the Standards reviewed.

Ensure that changes to facility systems have not compromised the ability of the modified SSC to perform its intended function. Review of tie-in points to existing facility systems

Evaluate constructability impacts due to field conditions.

Evaluate that modifications have not introduced siphoning effects.

Perform an ALARA checklist per Manual E7-1, Procedure DE-DP-710 on the verified scope.

\section{Notes / Caveats:}

The evaluation WILL NOT attempt to verify that the process source to which the system is tied, but it will ensure the upstream and downstream process safety conditions have not been jeopardized. For example, an electrical system modification will be analyzed to the process breaker sized for the existing load and the load from the modification. Likewise a water system will be analyzed for flow rate and pressure drop from the supply main to the modification use point but will not evaluate to the system supplying the main. Engineering management will accept the risk that the system will supply adequate flow rate, pressure or power. This assumes the evaluation scope in question is not the process system supply.

The evaluation will not review the design output for Economic Loss Impact(s).

This list is intended as guidance and may not be all inclusive for all conditions. Authorization Basis documents and reasonable engineering judgment should prevail. 